\title{
TEKS DAN KONTEKS KEPEMIMPINAN KAUM $T U A$ DALAM NASKAH-NASKAH TAREKAT SYATTARIYAH DI MINANGKABAU
}

\author{
Pramono \\ Universitas Andalas, Jl. Kampus Limau Manis Padang \\ e-mail: pramono_fsua@yahoo.co.id
}

\begin{abstract}
This article discusses the efforts of intreprating local Islam manuscripts of Minangkabau, particularly the order of Syattariyah in Minangkabau. The manuscripts are culturally important since they are related to the daily religious needs of the disciples of the order of Syattariyah in Minangkabau. This is related to the beliefs that to know about the guru, to posses the book, or to listen to the stories about the ulema, the guru of the order of Syattariyah are essential. The ideolgical perspectives is influenced by the surau teaching system based on the doctrines and books of the teachers. By means of social context analyses of the texts, it is found that one way to reflect the disciples' respect for the guru(-s) has been done through writing the biography of the respective teachers and understanding their teaching. Because the guru is considered holy man, his story cannot be written in Latin texts, otherwise it will be considered blasphemy or harâm.
\end{abstract}

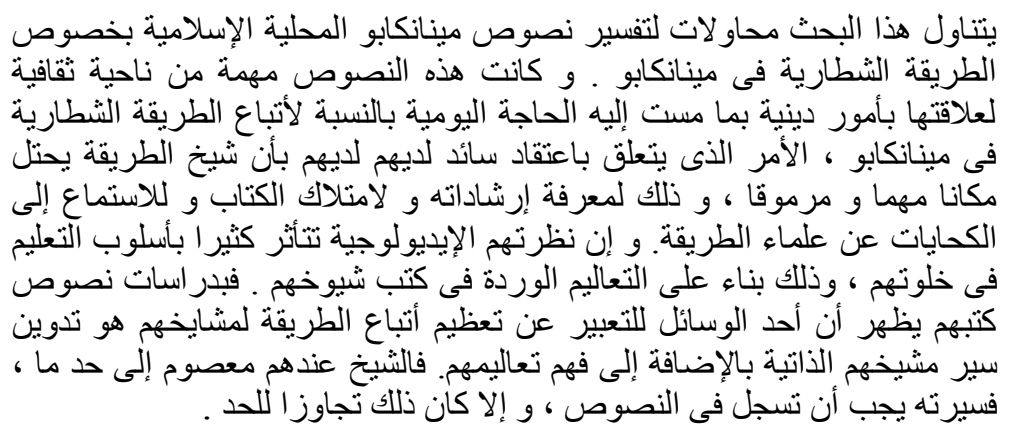

Kata Kunci: surau, Kaum Tua, Kaum Muda, manuscrip, Tarekat Syattariyah, Minangkabau, Islam. 


\section{PENDAHULUAN}

Minangkabau merupakan sukubangsa di Indonesia yang mendiami sebagian besar wilayah Provinsi Sumatera Barat. Etnis ini memiliki karakteristik yang unik, dalam hal hubungannya antara sosio-kultural dan Islam, dibandingkan sukubangsa-sukubangsa yang lain di Indonesia. Oleh karena itu, topik mengenai hubungan sosialkultural dan Islam di Minangkabau tetap menarik untuk didiskusikan.

Dalam konteks hubungannya dengan Islam, diketahui bahwa pada awal abad ke-19 hingga awal abad ke-20 di Minangkabau timbul dua macam aliran keagamaan, yaitu Kaum Tua dan Kaum Muda. Akan tetapi, sekarang ini kedua istilah tersebut mungkin sudah terasa asing dalam pendengaran kita. Sedang istilah yang banyak dipakai sekarang ini adalah "Kaum Tradisional" untuk Kaum Tua dan "Kaum Modernis" untuk Kaum Muda.

Perbedaan-perbedaan dalam berbagai amalan dan perilaku keagamaan di antara kedua kelompok itu hingga sekarang masih tetap ada. Organisasi-organisasi serta lembaga-lembaga pendidikan agama yang didirikan oleh masing-masingnya pun masih ada. Hal ini menunjukkan bahwa perbedaan pendapat antara kedua golongan itu masih tetap hidup dan berpengaruh dalam masyarakat Minangkabau.

Akan tetapi, buakan masalah perbedaan itu yang akan diulas dalam tulisan ini. Persoalan lain yang cukup menarik dan kurang mendapat perhatian adalah persoalan pola kepemimpinan Kaum Tua. Pembicaraan akan difokuskan pada peran pemimpin Kaum Tua dan bentuk penghormatan terhadap mereka.

\section{PERANAN ULAMA PEMIMPIN KAUM TUA}

Bagi masyarakat Minangkabau, "menjadi orang Minang berarti menjadi Muslim”. Jika ada orang Minang yang tidak memeluk, atau keluar dari, agama Islam misalnya, maka secara sosial mereka dapat dikucilkan. Dengan demikian, dari waktu ke waktu, masyarakat Minang berusaha menyesuaikan adat dan tradisi kemasyarakatannya dengan Islam. Upaya penyesuaian berbagai nilai Islam dengan adat di kalangan masyarakat Minangkabau ini tampaknya telah dimulai sejak orang Minang menerima Islam sebagai agamanya (Hamka, 1984:138). Persesuaian Islam dengan adat tersebut awalnya terjadi secara bertahap, ketika Islam mulai masuk dari wilayah pesisir (rantau) ke 
daerah pedalaman (darek). Dalam kosa-kata Minang, masuknya Islam dari wilayah rantau ke darek ini digambarkan dalam pepatah: syarak mandaki, adat manurun 'syarak mendaki, adat menurun', atau seperti yang ditulis Yusuf (2004:4), adaik dibao turun, syarak dibao naik 'adat dibawa turun, syarak dibawa naik'.

Kondisi seperti itu mempengaruhi masyarakat Minangkabau tentang persepsinya terhadap sosok ulama. Ulama bagi mereka tidak hanya penerang masa hidup di dunia, tetapi juga penyelamat untuk kehidupan di akhirat.

Dalam perjalanan sejarahnya, sosok ulama Minangkabau, khususnya ulama pemimpin Kaum Tua tidak hanya memiliki peran keagamaan saja. Akan tetapi, ulama pemimpin Kaum Tua di Minangkabau juag berperan di bidang sosial-budaya dan politik. Besarnya peran ulama pemimpin Kaum Tua di Minangkabau sempat mendapat perhatian khusus oleh Pemerintah Belanda pada masa penjajahan.

Pada masa penjajahan, Pemerintah Belanda mengerahkan beberapa orang sarjananya untuk mengadakan penelitian tentang tarekat yang ada di Sumatera Barat. Salah seorang di antaranya adalah Dr. Ph. S. Van Ronkel. Ronkel (dalam Latief, 1988:210) antara lain menyebutkan dalam laporannya pada tahun 1916 bahwa bahaya dari aliran-aliran tarekat bukanlah terletak pada unsur fanatismenya, melainkan terletak pada kepatuhan yang mutlak dari para anggotanya kepada pada syaikh yang memang menuntut kepatuhan itu sebagai haknya.

Khusus mengenai kaum Syattariyah, Ronkel menyebutkan bahwa para pemimpin tarekat Syattariyah itu biasanya adalah orangorang yang tangguh pengetahuannya, menjadi lawan bagi setiap aliran lainnya, suka mengejar-ngejar kekuasaan. Dengan demikian, tidak jarang merupakan sesuatu yang amat berbahaya bagi pemerintahan Belanda. Apabila terdapat kejadian-kejadian tertentu yang mereka cetuskan, dapat mengganggu kelancaran pemerintahan Belanda nantinya.

Dengan adanya ancaman tersebut, kemudian Pemerintah Belanda membuat strategi khusus untuk mengantisipasi potensi perlawanan dari kaum tarekat di Sumatera Barat. Dalam konteks ini, setidaknya ada dua strategi yang dibuat oleh Pemerintah Belanda. Pertama, mengadakan pengawasan yang ketat terhadap segala 
aktivitas yang dilakukan oleh kaum tarekat (Syattariyah). Dalam hal ini Pemerintah Belanda menempatkan seorang pengawas kelas tiga yang punya latar belakang ilmu Budaya. Belanda menempatkan seorang posthouder di Ulakan sejak tahun 1844 (Suryadi, 2004:117).

Kedua, dengan mendekati, membujuk dan memuji-muji para guru tarekat, dengan harapan agar mereka lebih memusatkan perhatian pada aktivitas kesufian, menjauhi urusan dunia. Dengan demikian, semangat jihad mereka yang sering menggangu kolonial akan dapat diredam. Sedang tokoh-tokoh tarekat yang dianggap berbahaya dan tidak mempan dibujuk, lalu diusir dari daerah ini atau dibunuh dengan berbagai cara yang licik (Latief, 1988:213-214).

Untuk kasus pusat tarekat Syattariyah di Ulakan Pariman, agaknya strategi Belanda ini berhasil. Hal ini dapat dicermati pada paroh pertma abad ke-19, di mana banyak pengikut tarekat Syattariyah di Ulakan Pariaman terpengaruh oleh gerakan pembaru Islam di Sumatera Barat. Golongan penganut tarekat Syattariyah yang terpengaruh oleh ide-ide pembaruan itu karena tidak puas dengan ulama Ulakan yang dinilai tidak memiliki komitmen untuk memerangi Belanda. Apalagi dalam kenyataanya Ulakan sebagai salah satu pusat tarekat Syattariyah tidak pernah benar-benar menunjukkan penentangannya atau setidaknya bersikap tegas terhadap Belanda yang dianggap kafir. Boleh jadi karena sifat tarekat Syattariyah (di Ulakan) yang suka pada harmoni, menyebabkan mereka cenderung menghindari konfrontasi dengan Belanda (Suryadi, 2004:117).

Dalam konteks itu, menarik jika dilihat dengan perspektif postkolonial. Di mana, perspektif postkolonial mencoba mengungkap akibat-akibat negatif yang ditimbulkan oleh kolonialisme. Akibatakibat yang ditimbulkan lebih bersifat sebagai degradasi mentalitas dibandingkan dengan kerusakan material. Oleh karena itu, akibatakibat yang dimaksud tidak berhenti secara serta merta setelah kolonialisme berakhir, melainkan berlangsung sampai sekarang, bahkan mungkin puluhan atau ratusan tahun (Ratna, dkk., 2006:74). Politik Belanda terhadap ulama tarekat Syattariyah di Ulakan, Padang Pariaman dengan cara memberikan penghargaan dan banyak pujian telah membuat mereka bersikap kompromi dengan Belanda. Secara mentalitas berbekas hingga hari ini, misalnya kekuatan Golkar yang telah mampu mendekati para ulama itu untuk berafiliasi ke dalam partai tersebut. Hal ini akan diterangkan lebih jauh di bagian setelah ini. 
Kondisi di atas sangat berbeda dengan ulama-ulama tarekat Syattariyah di Koto Tangah, Padang. Di wilayah ini Belanda mendapat perlawanan yang tajam dari mereka. Gambaran perlawanan ulama tarekat Syattariyah tersebut dapat ditemui dalam naskah Sejarah Surau Baru dan naskah Sejarah Syaikh Paseban karya Imam Maulana Abdul Manaf Amin al-Khatib.

Dalam naskah Sejarah Syaikh Surau Baru misalnya, diceritakan tentang pemberontakan rakyat Koto Tangah dan Pauh, Padang kepada Belanda di bawah pimpinan Pakih Mudo. Pakih Mudo adalah murid Syaikh Surau Baru yang diutus untuk mengislamkan rakyat Pauh, Lubuk Begalung dan sekitarnya. Ketika rakyat Koto Tangah dan Pauh, Padang berperang dengan Belanda yang dibantu oleh orang Kota Padang, maka Pakih Mudo mengomando rakyat Koto Tangah dan Pauh dalam peperangan itu.

Peperangan itu menyebabkan Syaikh Surau Baru ditawan Belanda. Penawanan itu dilaksanakan dengan alasan bahwa Pakih Mudo adalah murid Syaikh Surau Baru. Perang terjadi atas komando dan dorongan Syaikh Surau Baru. Dalam masa tawanan itulah Syaikh Surau Baru wafat dan tidak ada lagi yang melawan Belanda hingga ratusan tahun kemudian, yakni perlawanan ke Belanda yang dinamakan Perang Paderi yang dipimpin oleh Imam Bonjol. Kisah ini dapat ditemukan dalam kutipan teks berikut ini:

\begin{abstract}
Beginilah riwayat ringkas perjalanan hidup beliau Tuan Syaikh Surau Baru yang telah mengislamkan Koto Tangah, Pauh, dan sekitarnya. Juga beliaulah, Syaikh Surau Baru yang mula-mula melawan penjajah Belanda yang akan menginjakkan telapak kakinya di Pantai Minangkabau pada tahun 1658 Masehi (1076 Hijrat) yang bermaksud menjajah Minangkabau ... terjadi berkali-kali peperangan di Pauh dan Koto Tangah antara rakyat dengan tentara Belanda yang dibantu oleh laskar Padang yang telah takluk di bawah kekuasaan kompeni Belanda. Setelah Syaikh Surau Baru wafat ditawan kompeni Belanda barulah habis perlawanan rakyat terhadap kompeni Belanda. Maka amanlah Belanda di Padang sampai 170 tahun kemudian barulah ada kembali perlawanan terhadap Belanda yang (di)kepalai oleh Tuanku Imam Bonjol yang dinamai Perang Paderi mulai tahun 1803 berakhir tahun 1837 (Al-Khatib, t.th.:51-52).
\end{abstract}

Selain Syaikh Surau Baru, perlawanan terhadap Belanda juga dilakukan oleh ulama tarekat Syattariyah di Koto Tangah, Padang yaitu, Syaikh Paseban. Perlawanan Syaikh Paseban. pada waktu itu 
adalah dengan tidak bersedia membayar pajak kepada pemerintahan Belanda di Kota Padang. Karena perbuatannya tersebut, ia ditangkap dan dipenjarakan oleh Belanda. Selain itu, pernah suatu kali Belanda dengan taktiknya akan memberikan penghargaan kepada Syaikh Paseban. Penghargaan tersebut berupa bintang jasa yang oleh Belanda dikatakan bahwa Syaikh Paseban berhak menerima karena ia adalah ulama besar yang telah banyak berjasa bagi kaumnya. Akan tetapi, penghargaan itu ditolak oleh Syaikh Paseban. "Yang akan memberi saya bintang adalah Tuhan, tidak Belanda, " kata Syaikh Paseban (AlKhatib, 2001:29, 34).

Dalam konteks perlawanan tersebut, dalam naskah Sejarah Ringkas Syaikh Paseben Asyattari Rahimahullah Taala Anhu, penulisnya kembali menegaskan tentang kepahlawanan Syaikh Surau Baru. Dalam salah satu bagian teks disebutkan bahwa, Syaikh Paseban selalu mengadakan ziarah ke makam Syaikh Surau Baru di Batusingka, Air Dingin, Koto Tangah, Padang. Adapun bunyi teksnya, sebagai berikut:

...adalah di suatu makam Syaikh Muhammad Natsir (Syaikh Surau Baru). Syaikh Surau Baru ini adalah orang Kota Panjang, Kota Tengah, Padang. Beliau sama pergi menuntut ilmu dengan Syaikh Burhanuddin ke Aceh kepada Syaikh Abdurrauf (Syaikh Kuala). Beliaulah, Syaikh Surau Baru inilah yang mengislamkan Negeri Kota Tengah, Pauh, Lubuk Bagalung (Negeri yang dua puluh) dan Negri Padang. (ketiga) Jasa beliau Syaikh Surau Baru, beliaulah yang mulanya melawan Belanda di Minangkabau ini, 170 tahun (seratus tujuh puluh tahun) sebelum Tuanku Imam Bonjol. Syaikh Surau Baru melawan Belanda waktu Belanda akan menjejakkan kakinya di Pantai Padang sedangkan Tuanku Imam Bonjol mengusir Belanda yang telah menduduki Minangkabau. Itu perbedaan perjuangan Syaikh Surau Baru dengan Syaikh Paseban. Beliau Syaikh Surau Baru dapat ditawan Belanda dimasukkannya ke dalam rajam dan wafat di situ dan Tuanku Imam Bonjol ditawan Belanda dibuangnya ke Manado dan wafat di situ (Al-Khatib, 2001:39).

Agaknya penulis naskah ingin mempertegas bahwa Syaikh Surau Baru, ulama tarekat Syattariyah di Koto Tangah, Padang adalah benar-benar berjiwa pahlawan. Hal ini juga sekaligus mempertegas bahwa ulama tarekat Syattariyah di Koto Tangah, Padang selain orang alim juga anti penjajah. Oleh karena itu, pengikutnya harus menghormatinya agar beroleh berkah. 
Setelah Indonesia merdeka, Wakil Presiden Republik Indonesia, M. Hatta, memaklumatkan agar menumbuhkan berbagai organisasi dan partai. Hal ini untuk menolak tudingan Belanda bahwa Indonesia bukanlah negera yang sah. Setelah adanya maklumat ini, maka banyaklah lahir parta-partai di negeri ini, termasuk juga di Sumatera Barat (Nasution, 2002:899). Salah satu organisasi sosial yang berikutnya menjadi sebuah partai di Sumatera Barat adalah Persatuan Tarbiyah Islamiyah (Perti). Pada awalnya, Perti adalah organisasi sosial yang didirikan pada tanggal 5 Mei 1930 di Candung, Bukittinggi. Pendirinya adalah para ulama yang terdiri dari Syaikh Sulaiman ar-Rasuli Candung, Syaikh Muhammad Abbas al-Kadi Bukittinggi, Syaikh Muhammad Jamil Jaho Padangpanjang dan Syaikh Abdul Wahid Tabekgadang. Perti mengikuti aliran Ahlul Sunnah wal Jamaah dalam itikad dan mazhab Syafi'i dalam syariat dan ibadat. Sejak 22 Nopember organisasi sosial ini berubah menjadi partai politik dengan nama Partai Politik Islam Perti (Nasution, 2002:899).

Kondisi seperti itu juga ikut mempengaruhi pandangan ideologis tarekat Syattariyah di Koto Tangah, Padang. Dalam naskah otobiografi Sejarah Imam Maulana Abdul Manaf Amin al-Khatib disebutkan bahwa, menjelang Pemilihan Umum pertama 1955, penduduk Koto Tangah sudah tujuh puluh lima persen masuk ke dalam Partai Islam Perti. Hal ini dikarenakan ulama-ulama yang berwibawa -termasuk Imam Maulana Abdul manaf Amin al-Khatibtarekat Syattariyah di Koto Tangah telah masuk ke dalam partai itu (Al-Khatib, 2002:47).

Dalam konteks kepartaian tersebut, Imam Maulana Abdul Manaf Amin al-Khatib pernah giat memperjuangkan Partai Islam Perti di Koto Tangah, Padang. Menurut penuturannya, pada waktu menjelang Pemilihan Umum pertama 1955, ia giat mengkampanyekan Partai Islam Perti. Poster-poster dan simbol-simbol partai ia buat sendiri dan dengan biaya sendiri. Tidak hanya itu, ia juga menempelkan poster-poster itu di berbagai tempat di Koto Tangah, Padang yang dilakukannya sendiri. Hal ini ia lakukan tidak lain karena menginginkan pilihan penduduk Koto Tangah, Padang tidak salah, yakni partai Islam yang sesuai dengan paham tarekat Syattariya. Hal ini memang terlihat agak berlebihan, padahal ia bukanlah pengurus atau pejabat dalam tubuh Partai Islam Perti itu. 
Hal itu dimungkinkan karena Imam Maulana Abdul Manaf Amin al-Khatib benar-benar terhimbau oleh anjuran Pemerintah pada waktu itu. Pada waktu itu Pemerintah melalui Wakil Presiden Muhammad Hatta menganjurkan bahwa setiap warga masyarakat untuk masuk ke dalam salah satu partai. Jika tidak masuk ke dalam salah satu partai, maka orang tualang 'orang lepas, orang yang tanpa ikatan sebuah sistem aturan (Pemerintah)' namanya, dan Pemerintah tidak menjamin keamanan orang seperti itu. Oleh karena itu, dengan banyak pertimbangan dan dari hasil pengamatan Imam Maulana Abdul Manaf Amin al-Khatib, Partai Islam Perti-lah yang sesuai dengan paham tarekat Syattariyah. Dalam hal ini ia mengatakan bahwa:

\footnotetext{
...setelah saya selidiki beberapa partai Islam sePerti Masyumi, Nahdatul Ulama, Partai Serikat Islam, dan Partai islam Perti, maka jatuhlah pilihan saya kepada Perti. Sebab partai ini berdasarkan mazhab Syafi'i dan beritikad ahlul sunnah waljamaah (Al-Khatib, 2002:6).
}

Menarik dikemukakan bahwa, menjelang Pemilihan Umum pertama tahun 1955 — saat di mana masing-masing partai gencar berkampanye mencari dukungan - terjadi ketegangan hubungan antara Imam Maulana Abdul Manaf Amin al-Khatib dengan Angku Talaok akibat perbedaan pilihan partai di antara mereka (al-Khatib, 2002:47-57). Di satu sisi, Angku Talaok bergabung dengan Partai Islam Indonesia (PII), sementara di sisi lain, Imam Maulana Abdul Manaf Amin menjadi anggota Partai Islam Perti. Pada awal tahun 1950-an Angku Talaok pernah diminta oleh para penganut tarekat Syattariyah di Batang Kabung dan sekitarnya untuk membantu mengajar di beberapa surau mereka. Saat itu, yang telah lebih dahulu mengajar di surau Batang Kabung, dan beberapa surau lain di sekelilingnya, adalah Imam Maulana Abdul Manaf Amin.

Polemik tentang partai juga dialami oleh Imam Maulana Abdul Manaf Amin al-Khatib di era Orde Baru. Ia pernah bersilang pendapat dengan Angku Inyik Adam, khalifah tarekat Syattariyah dari Syaikh Paseban, yang sebetulnya merupakan kawan seperguruan Imam Maulana Abdul Manaf Amin al-Khatib sendiri ketika belajar dengan Syaikh Paseban. Saat itu, Angku Inyik Adam mengajaknya untuk masuk ke dalam partai Golkar, agar mudah mendapat bantuan dari 
Pemerintah untuk renovasi makam Syaikh Surau Baru di Batusingka, Koto Tangah, Padang. Akan tetapi, ajakan itu ditolak oleh Imam Maulana Abdul Manaf Amin. Dalam hal ini menarik disimak penolakan ajakan untuk masuk ke partai Golkar oleh Angku Inyik Adam berikut ini.

\footnotetext{
Begini Inyik, adapun Beliau ini (Syaikh Surau Baru -pen.) bukan orang partai, bukan pula ziarah bersama ini (bersyafar) tidak atas nama partai. Bersyafar ini adalah atas nama kaum muslimin, tidak dihitung partainya ... Kalau saya masuk Golkar berarti ziarah bersama (bersyafar) ini tentu Syafar orang Golkar kata orang (Al-Khatib, 2002:63).
}

Penting dikemukakan di sini bahwa, banyak dan bahkan sebagian besar pengikut tarekat Syattariyah di Sumatera Barat yang masuk ke partai Gokar setelah Perti kembali berstatus organisasi nonpolitik. Perti mengalami perpecahan di dalam tubuh organisasinya dengan adanya pro dan kontra terhadap gagasan Nasakom yang dicetuskan oleh Soekarno. Kemelut yang kurang terbenahi ini sangat merugikan bagi tujuan semula organisasi. Pengelolaan bidang pendidikan dan dakwah seolah-olah terlupakan kalau tidak dapat dikatakan terabaikan sama sekali. Maka pada tahun 1969, Syaikh Sulaiman ar-Rasuli, pendiri organisasi ini yang masih hidup pada waktu itu, mendekritkan agar kembali kepada khittah semula, yaitu status nonpol, bergerak di bidang sosial. Dekrit ini hanya diterima oleh sebagian saja yang dipimpin oleh putranya K.H. Burhanuddin arRasuli, dan kemudian dalam menyalurkan aspirasi politiknya bergabung dengan Golkar.

Berbagai argumen muncul dari ulama-ulama tarekat Syattariyah yang bergabung ke dalam partai Golkar. Bagi orang awam, menurut mereka pilihan guru kepada Golkar adalah petunjuk Allah yang harus diterima. Bagi yang sedikit maju dan cerdas, mereka mengajukan dalil, daripada kita menumpang kapal kecil lebik baik naik kapal besar, yakni Golkar. Ada lagi alasan ulama bahwa merubah dan memperbaiki dari dalam jauh lebih mudah daripada memperbaiki dari luar. Dengan masuk ke dalam Golkar, menurut mereka, akan lebih mudah untuk memberikan pelajaran tarekat kepada orang-orang yang berada di dalam Golkar, yang banyak sekuler dan bercampur agamanya (Samad, 2003:266). 
Akan tetapi, ada juga ulama tarekat Syattariyah yang dengan tegas menolak bergabung dengan Golkar. Misalnya, almarhum Tuanku Salif dari Sungai Sarik, Padang Pariaman yang lama mengajar di Batang Kabung, Koto Tangah, Padang. Menurut ulama ini, ulama yang mencampuradukkan diri dengan politik itu adalah khianat pada tugas keulamaannya (Samad, 2003:268). Sangat dimungkinkan bahwa Imam Maulana Abdul Manaf Amin al-Khatib yang juga menolak ajakan masuk ke Golkar karena terpengaruh sikap Tuanku Salif ini. Hal ini jika dikaitkan dengan kecenderungan pendapat ulama dalam tarekat Syattariyah yang besar pengaruhnya terhadap sikap kaumnya.

\section{PENGHORMATAN TERHADAP ULAMA PEMIMPIN KAUM $T U A$}

Di kalangan Kaum Tua di Minangkabau, penghormatan kepada ulama-ulama pemimpin mereka terlihat pada gelar-gelar yang diberikan, misalnya sebutan Tuanku, Inyiek, Syaikh dan Maulana. Bentuk penghargaan yang lain terlihat juga dalam pelestarian cita-cita dan perjuangan ulama terdahulu, penulisan riwayat hidupnya, penyebaran buku-buku hasil karyanya. Bentuk penghargaan yang terakhir ini sangat menarik dan penting untuk dijelaskan.

Dalam konteks penghargaan ulama pemimpin Minangkabau dalam bentuk penulisan riwayat hidupnya dan penyebaran buku-buku hasil karyanya banyak ditemukan di Minangkabau. Salah satu bentuk penghargaan itu adalah naskah-naskah karya Imam Maulana Abdul Manaf Amin al-Khatib. Ia banyak menulis sejarah para syaikh dan ajaran-ajarannya. Dalam teks yang terdapat dalam hamper seluruh naskah karya Imam Maulana Abdul Manaf Amin al-Khatib menempatkan guru sebagai orang yang harus dihormati. Dengan menulis sejarah guru atau syaikh, maka akan mendapat berkah dan keselamatan baik di dunia maupun di akhirat. Hal ini dapat dilihat dalam kutipan berikut ini.

...sudah jelas oleh kita bahwa Nabi kita Muhammad S.M menyuruh kita menghormati dan memuliakan ulama. Begitu pula ikan-ikan dalam laut, yang kesimpulannya penghuni langit dan bumi menghormati ulama. Tentu kita lebih menghormati ulama dari pada mereka. Mudah-mudahan dengan menulis sejarah beliau, Syaikh Paseban ini, maka saya termasuk orang yang dianjurkan Nabi tadi, yaitu orang yang menghormati dan memuliakan ulama dan mudah- 
mudahan Allah memberi berkat atas usaha saya. Amin amin ya rabbil 'alamin. Saya yang menulis adalah salah seorang dari murid beliau yang bernama Haji Imam Maulana Abdul Manaf Amin al-Khatib. Batang Kabung, Padang (Al-Khatib, 2001: 12-13).

Ajaran guru adalah sesuatu yang benar dan tidak boleh dibantah. Jika ada golongan lain mengkritik ajaran guru, maka harus diluruskan. Berikut ini dapat dilihat gambaran tentang bantahan terhadap kritikan dari pihak luar.

...dengan adanya ketiga buku sejarah ini dapatlah saudara-saudara
yang menjadi pengikut dan pencinta Syaikh Abdurrauf dan Syaikh
Burhanuddin mengetahui bagaimana beliau-beliau ini
mengembangkan agama Islam dan dapat kejelasan apakah mazhab
beliau, apakah bilangan yang beliau pakai untuk menentukan tanggal
satu hari bulan Arab. Sebab, akhir-akhir ini banyak pula keluar di
surat-surat kabar dan majalah-majalah yang memutarbalikkan sejarah
beliau yang berdua ini yang jauh berbeda dengan yang dalam buku ini.
Tidak surat-surat kabar dan majalah saja yang memutarbalikkan
sejarah beliau-beliau ini. Tetapi juga guru-guru tarekat kampung
memutarbalikkan pula sejarah Syaikh Abdurrauf dan sejarah Syaikh
Burhanuddin, supaya tarekatnya diterima oleh orang kampung yang
buta ilmu pengetahuan agama. Demikianlah supaya kita berhati-hati
menerima sejarah dan menerima tarekat dari guru tarekat, jangan asal
dimasuki saja (Al-Khatib, 1936:5).

Perlu dijelaskan di sini bahwa, yang dimaksud dengan "ketiga buku sejarah ini" dalam kutipan di atas oleh Imam Maulana Abdul Manaf Amin al-Khatib adalah teks sejarah Syaikh Abdurrauf, Syaikh Burhanuddin, dan Syaikh Surau Baru. Penulisnya mengharapkan bahwa dengan adanya ketiga sejarah syaikh tersebut, maka pengikut tarekat Syattariyah akan memahami bagaimana ketiganya beramal ibadah, bagaimana mereka menentukan awal bulan Arab, dan seterusnya.

Karena suatu paham yang tidak sesuai atau berlainan dengan fatwa guru yang diterimanya, maka tidak boleh mengikut paham tersebut, paham gurulah yang benar. Misalnya, sebagian besar pengikut tarekat Syattariyah tidak akan salat Jumat apabila khotbah dilaksanakan tidak menggunakan bahasa Arab. Mereka tidak akan ikut salat tarawih di bulan Ramadan, jika salatnya dilakukan sebanyak sebelas rakaat, karena menurut fatwa gurunya yang benar adalah mengerjakan salat tarawih itu dua puluh tiga rakaat. Untuk 
menentukan awal bulan Ramadan dilakukan dengan ru'yah (melihat bulan) terlebih dahulu, walaupun Pemerintah telah mengumumkan awal memasuki puasa Ramadan.

Menghormati guru juga diyakini berimplikasi terhadap cepatnya pemahaman ilmu yang diajarkan oleh sang guru. Jika patuh dan hormat terhadap guru, maka pemahaman ilmu akan datang dengan tidak disangka-sangka. Dalam teks sejarah Syaikh Abdurrauf Singkil misalnya, dikisahkan tentang bagaimana bentuk penghormatannya kepada gurunya, Syaikh Ahmad al-Qusyasyi, seperti berikuit ini:

...tetapi pelajaran [bang] yang [berikan] diberikan oleh Syaikh Ahmad Qusyasyi hanya surat al-Baqarah saja, tidak birasak-birasak sekedar lamanya. Artinya itu-itu saja pelajaran yang diberikan oleh Syaikh Ahmad al-Qusyasyi hingga sampai kepada masa akan kembali pulang. Namun, begitu hati beliau terhadap guru tidak menaruh bosan dan berkecil hati. Malahan beliau terima hal yang demikian dengan hati yang ikhlas dan bertawakal kepada Allah Subhanahu Wata'ala. Beliau tetap hormat dan khidmat serta patuh terhadap guru beliau. Selain menuntut ilmu juga kerja beliau Syaikh Abdurrauf di Madinah adalah mengembalakan unta Tuan Syaikh Ahmad al-Qusyasyi tiap-tiap hari. Tambahan lagi, sebagai mengkhidmati guru beliau tetap mendukung guru dari tempat tinggalnya kepada tempat dia mengajar ilmu di Masjid Nabawi. Begitulah kerja beliau Syaikh Abdurrauf tiap-tiap harinya, yaitu pagi-pagi didukung guru di hulu dari tempat tinggalnya ke tempat dia mengajar. Sudah itu terus pergi gembala unta ke tengah padang. Begitu pula petang-petangnya setelah memasukkan unta ke kandanganya maka pergi pula menjemput guru ke mesjid, di dukung pula ke tempat tinggal beliau. Sangat patuh dan sangat hormat kepada guru apa yang diperintahkannya oleh guru tidak pernah membantah dan waktu bersalam mencium tangan guru (Al-Khatib, 1936:8-9).

Dalam teks sejarah Syaikh Burhanuddin juga dikisahkan tentang bentuk penghormatan yang dilakukan kepada gurunya, Syaikh Abdurrauf Singkil, seperti berikut ini.

Adapun kaji yang diberikan oleh Syaikh Abdurrauf kepada Burhanuddin adalah surat al-Fatihah saja tidak berasak-asak sekedar lamanya. Adapun adab dan tertib Burhanuddin kepada gurunya Syaikh Abdurrauf di dalam menuntut ilmu tidak ada ubahnya seperti adab dan tertib Syaikh Abdurrauf pula terhadap gurunya, Syaikh Ahmad alQusyasyi, yaitu mendukung guru dari tempat tinggalnya ke tempat mengajar, yaitu di masjid. Selain mendukung guru juga Burhanuddin menggembalakan ternak Syaikh Abdurrauf, yaitu kambing tiap-tiap hari, dan lagi menggali tebat (kolam) ikan di sekeliling masjid. 
Begitulah kerja Burhanuddin selama menuntut ilmu di Aceh dalam masa tiga puluh tahun... (Al-Khatib, 1992:20-21).

Kedua kutipan di atas, menggambarkan sekaligus mendorong kepatuhan murid kepada guru. Kepatuhan itu akan membawa berkah, sehingga pelajaran diperoleh dengan mudah dan sempurna. Di samping itu, kedua kutipan tersebut juga berpesan kepada pembacanya bahwa sebuah ilmu tidaklah diperoleh dengan mudah. Ia harus diperoleh dengan perjuangan yang sungguh-sungguh tidak kenal menyerah. Amanat "tidak kenal menyerah" itu senantiasa terwaris dari guru yang satu ke guru berikutnya.

Teks-teks yang terkandung dalam naskah-naskah karya Imam Maulana Abdul Manaf Amin al-Khatib, banyak sedikitnya memperlihatkan pandangan tentang hubungan guru-murid yang secara eksplisit mengarahkan agar para murid dan pengikut tarekat Syattariyah merasa (ataupun diwajibkan) mengenal riwayat syaikh yang menjadi gurunya atau guru dari gurunya. Bagi para penganut tarekat Syattariyah, mengetahui riwayat guru adalah sebuah keharusan karena itu bermakna penghormatan kepada guru, adab kepada guru, untuk kemudian menjadi suri teladan bagi kehidupannya. Oleh karena itu, orang berusaha untuk memiliki, membaca ataupun mendengar orang membacakan riwayat gurunya, memuliakan guru agar mendapat syafaatnya (limpahan rahmat), agar ilmu yang didapat beroleh berkah.

Karena merasa "wajib" untuk mengetahui riwayat dan ajaran para syaikh tersebut, banyak kalangan penganut tarekat Syattariyah, khususnya di Koto Tangah, Padang yang ingin memiliki naskahnaskah karya Imam Maulana Abdul Manaf Amin al-Khatib. Perihal banyaknya peminat naskah-naskah karyanya itu, menarik untuk dipaparkan tentang sejarah teks yang menceritakan sejarah Syaikh Abdurrauf, Syaikh Burhanuddin, dan Syaikh Surau Baru.

Dari naskah-naskah itu jelas bahwa syaikh sebagai pemimpin menjadi sentral dalam pembentukan ideologi penganut tarekat Syattariyah Kaum Tua) di Minangkabau. Seorang guru melalui prosesi bai'ah yang sudah dilakukan sebelumnya, sebagai sumpah setia murid kepada gurunya, dapat memperlakukan muridnya sesuai dengan aturan yang ditetapkan. Perintah dan larangan guru bersifat mutlak dan mengikat. Sebaliknya, murid secara sukarela harus menerima dan mematuhi segala bentuk aturan yang telah ditetapkan guru kepadanya. 
Murid tidak boleh banyak mempertanyakan tentang "mengapa" dan "apa sebabnya", apalagi membantah guru. Oleh karena itu, di kalangan Syattariyah berlaku ungkapan bahwa "seorang murid di hadapan guru ibarat sesosok mayat di tangan orang yang memandikannya" (Samad, 2003:147-148).

Selain itu, penghormatan dan penghargaan terhadap guru, dalam pengajian tarekat Syattariyah dilakukan atas dasar pandangan bahwa guru adalah orang yang suci dan dekat kepada Allah. Bahkan penghormatan yang demikian masih terus berlangsung meskipun guru yang bersangkutan telah meninggal dunia. Dalam pandangan mereka roh seorang syaikh yang sudah meninggal masih dapat memberikan pertolongan kepada murid-muridnya. Karena itu, mereka selalu berziarah mengunjungi makam untuk mendapatkan berkah sekaligus sebagai bukti kesetiaan terhadap guru tersebut.

Sebaliknya, kedurhakaan terhadap syaikh akan menimbulkan malapetaka bagi murid-murid. Kedurhakaan terhadap syaikh akan berakibat luas terhadap kehidupan murid, baik secara duniawi maupun setelah ia meninggal. Setidaknya menurut keyakinan mereka, ada tiga hal yang akan terjadi bagi seorang murid yang durhaka kepada gurunya, yaitu (1) Allah akan menyepitkan rejekinya di dunia; (2) Allah akan mencabut berkat ilmu yang telah dipelajarinya dari sang guru; dan (3) Tatkala jiwa akan berpisah dengan badan (meninggal), Allah akan mencabut iman yang ada di dada murid, sehingga dia mati dalam keadaan tidak beriman (Al-Khatib, 1992:30).

\section{PENUTUP}

Pertemuan Islam dengan budaya lokal Minangkabau telah menjadikan corak kepemimpinan yang khas. Lebih khas lagi tampak pada pola kepemimpinan Kaum Tua di Minangkabau. Para ulama pemimpin Kaum Tua itu berperan tidak hanya di bidang keagamaan saja, tetapi juga di bidang sosial-budaya dan politik. Suaranya didengar, tingkah lakunya diikuti; sebagai penerang di dunia bahkan sampai di akhirat. Mereka dihormati, riwayat dan ajarannya ditulis dan disebarkan. Tulisan itu memberikan sumbangan yang sangat berarti bagi kemajuan ummat, khususnya dalam membangun kepribadian dan moral. Di antara sumbangannya yang dapat dicatat adalah sebagai berikut ini. Pertama, riwayat dan ajarannya dijadikan rujukan untuk pengambil keputusan, tidak hanya masalah keagamaan tetapi juga 
masalah sosial budaya serta politik yang mereka hadapi; dan kedua, penghormatan terhadap pemimpin memberikan tauladan agar murid pun harus berperilaku (beribadah) seperti sang guru: pola hidup sederhana (zuhud)dan tidak ambisius (qanâ'ah).

\section{DAFTAR PUSTAKA}

Hamka. 1984. Islam dan Adat Minangkabau. Jakarta: Pustaka Panjimas

Latief, M. Sanusi. 1988. Gerakan Kaum Tua di Minangkabau. Disertasi tidak diterbitkan. Jakarta: PPs IAIN Syarif Hidayatullah Jakarta.

Nasution, Harun (Ketua Tim). 2002. Ensiklopedi Islam Indonesia .Jilid 3 OZ. Jakarta : Djambatan.

Ratna, Nyoman Kutha, dkk. 2006. Postkolonialisme Indonesia. Laporan Penelitian tidak diterbitkan. Denpasar: PPs Kajian Budaya Universitas Udayana.

Samad, Duski. 2003. Tradisionalisme Islam di Tengah Modernisme: Kajian Tentang Kontinuitas, Perubahan, dan Dinamika Tarekat di Minangkabau. Disertasi tidak diterbitkan. Jakarta: PPs UIN Syarif Hidayatullah Jakarta.

Suryadi. 2004. Syair Sunur: Teks dan Konteks Otobiografi Seorang Ulama Minangkabau Abad Ke-19. Padang: Citra Budaya.

Yusuf, M., dkk. 2004. Manuskrip dan Skriptorium Minangkabau. Laporan Penelitian tidak diterbitkan. Kelompok Kajian Puitika Fakultas Sastra Unand.

\section{MANUSKRIP}

al-Khatib, Imam Maulana Abdul Manaf Amin. t.th. Sejarah Ringkas Shaikh Muhammad Nasir (Syaikh Surau Baru). naskah tulisan tangan koleksi Imam Maulana Abdul Manaf Amin, Batang Kabung, Koto Tangah, Padang Sumatra Barat.

- 1936. Inilah Sejarah Ringkas Auliyaullah al-Salihin Syaikh Abdurrauf (Syaikh Kuala) Pengembang Agama Islam di Aceh. naskah tulisan tangan koleksi Imam Maulana Abdul Manaf Amin, Batang Kabung, Koto Tangah, Padang Sumatra Barat.

1992. Inilah Sejarah Ringkas Auliyaullah al-Salihin Syaikh Burhanuddin Ulakan yang Mengembangkan Agama Islam di Daerah Minangkabau. Naskah tulisan tangan koleksi Imam Maulana Abdul Manaf Amin, Batang Kabung, Koto Tangah, Padang Sumatra Barat. . 2002. Kitab Riwayat Hidup Imam Maulana Abdul Manaf Amin. naskah tulisan tangan koleksi Imam Maulana Abdul Manaf Amin, Batang Kabung, Koto Tangah, Padang Sumatra Barat 
Jurnal Hunafa Vol. 6, No. 1, April 2009: 1-16

2001. Sejarah Ringkas Syaikh Paseban al-Syatari Rahimahulallahu Taala. naskah tulisan tangan koleksi Imam Maulana Abdul Manaf Amin, Batang Kabung, Koto Tangah, Padang Sumatra Barat. 